\title{
From Practice to Writing: Using Reflective Journal Instruction in Enhancing Pre-Service Teachers' Professional Development
}

\author{
Remart Padua Dumlao \\ University Foreign Lecturer, Muban Chombueng Rajabhat University, Thailand, \\ dumlaoremart25@gmail.com
}

\section{Jonathan Ramirez Pinatacan}

University Foreign Lecturer, Rajamangala University of Technology Phra Nakhon, Thailand, jonburma2011@gmail.com

Journal writing as a way of reflective instruction has now become popular in second/foreign language teacher education due to its contribution for educational development and instruction, yet little studies have been conducted about preservice teachers' reflection while teaching in a foreign classroom. This article investigates the experiences of 13 BSE majoring in English language teaching preservice teachers in reflective journal writing during their teaching practice in a foreign classroom. Drawing from qualitative data, the findings suggested that the participants perceived journal writing as a way reflective practice in three main ways: (a) pre-service teachers personal development, (b) pre-service teachers selfefficacy, (c) pre-service teachers professional formation. The study implicates that teacher education courses should incorporate journal writing as an explicit tool that serves as a reflection frame for teacher candidates' ongoing professional language learning and growth as practitioners in the field of language teaching.

Keywords: pre-service teachers, journal writing, reflective practice, EFL, instruction

\section{INTRODUCTION}

Earlier work in the broader literature of teacher education has highlighted the significant role of reflective practice through journal writing in teachers learning and development, as it helps teachers to be aware of their own knowledge (e.g., pedagogical, conceptual, theoretical), own teaching strategies, and evaluating their own performances (Bruster \& Peterson, 2013; Haugan \& Moen, 2013; Zach \& Stock, 2018). In spite of its importance, reflective journal writing is unfortunately undeveloped platform in pre-service teachers' training instruction. To be a reflective practitioner, it is argued that teacher institute must encourage their pre-service teachers to use reflective journal as a way of evaluating and monitoring their teaching practices, particularly the weaknesses and strengths of their 
daily activities (O’Brien, 2016; Orland-Barak \& Yinon, 2007). In this sense, they could be a more effective teacher in their immediate and future teaching context (Lee,2007; Minott, 2009; Al-karasneh, 2014).

Furthermore, previous studies have reported that journal writing could provide an adequate blue print to improve both the quality of teaching and instruction (Teekman, 2000; Bolton, 2005), facilitates persistent way to act about "one's practice" (Garza \& Smith, 2015:12), and represent "what do and do not" while teaching (Garza \& Smith, 2015:324; Thompson \& Pascal, 2012; Zulfikar \& Mujiburrahman, 2017). Along with this growth in teacher education, however, there is increasing concern over in terms of time management (Hickson, 2011; Moon, 2004; Collin et al., 2013), difficult to qualify which of those reflections have already occurred during the teaching practice (Gould \& Taylor, 2017), and it brings burden to pre-service teachers' load in teaching practice (Gadsby \& Cronin, 2012; Burgoyne \& Chuppa-Cornell, 2018). This paper contests the claim on how reflective writing really help or effect pre-service teachers' development. Thus, this present study aims at identifying the prevalence of reflective practices through reflective journaling of pre-service English teachers teaching in a foreign classroom, is expected to provide guidance in filling the gap in the field of study.

\section{Journal Writing in Pre-Service Teachers Preparation}

A number of researchers have highlighted journal writing as reflective practice and as way of preparing pre-service teachers in the field of teaching. This may also help prospective teachers; as pre-service teachers could narrate their learning experiences through writing (Bolton, 2005). These writing artifacts would be treated as rich resources of information which at least inform all members of the academic community (Akbari, 2007; Nguyen, 2017) of "what and how to be a beginner in the field" of teaching (Johnson \& Golombek, 2011:67). Give the fact that writing a reflective journal is a complex task for pre-service teachers to accomplish due to their teaching loads and other task given by their immediate context (Burton, 2009; Buron \& Carroll, 2001a), it is also acknowledged that through reflective journaling, pre-service could assess their critical thinking and prepared them in their future teaching endeavor (Khanjani et al., 2018).

Spadling and Wilson (2002), outline the significant role of journal writing which promotes not only for reflective thinking but also critical thinking. First, journals serve as a permanent record of thoughts and experiences. This means that teachers could have a chance to review their performance as records are available to them. Then, through journal writing, it is argued that pre-service teachers could establish academic relationship with their supervisor/teacher, and thus help them through the process of teaching. Lastly, journal writing would also help pre-service teachers to realize their existence in the community of teaching.

Consequently, Thorpe (2004) argues that through the reflection of pre-service teachers, it encourages teachers or readers to be part of the reflection process, as they are obliged to evaluate, judge, or even question the pre-service teachers' daily practices. Together, it can be seen that journal writing can promote holistic development of pre-service 
teachers in the field as it increases critical and creative thinking (Carosotto, 2017; Choy \& OO, 2012; Lee, 2007; Leitch \& Day 2000; Ross, 2011); avenue to check their teaching abilities (Moradkhani et al.,2017; Pavlovich,2007; Roux et. al., 2012); realize their teaching philosophy (Glogger et al., 2012; Liu \& Milman, 2010; Farrell, 2013; Grushka et al., 2005; Moo, 2000); construction of their own professional and metaphorical identity (Richard \& Farrell, 2005; Abednia et al., 2013; Bolton, 2010); and develop their teaching practices (Burton, 2009; Grushka et al., 2005; Moo, 2000) to be a more effective and competent teacher of the century. The generalizability of much published research on this issue is problematic, particularly in a foreign classroom where TESOL pre-service teachers are present.

\section{Reflective Instruction as Professional Development}

In the past two decades, a number of researchers have documented the benefits of training methods for reflective teaching as professional development. Owing to the fact that it provides more benefits rather than drawback, the teacher education programs are becoming more demanding in the developmental use of reflective instruction to the student teachers. These programs aim to aid novice teachers in the field to be more cautious in decision making processes to help them identify the outcomes of their decisions in the context in which they applied or utilized in it. However, a number of these studies have focused only on teachers' perceptions, beliefs, issues and challenges with regards to reflective practicing, relatively few in pre-service teachers teaching in a foreign classroom. For instance, Haugan et al. (2013) explores the Norwegian student teachers' reflective where they found out that reflective teaching offers pre-service teachers the avenue to recheck or evaluate their development in teaching. Similarly, Shu-ping (2012) explored a case study dealing with university teachers and third year students. Findings revealed that writing a journal as tool of reflective practice could bring awareness to EFL teachers in developing their professionalism in the field of teaching. These studies suggested that reflecting practice through journal writing is a good way to develop teachers' professionalism (Lakshmi, 2012; Farrell, 2013).

Similarly, Chien (2013) investigates journal writing of two elementary school English teachers. Through semi-structured interview, findings indicated the advantages of using reflective journal in classroom practise such as monitoring of participants' performances, guidelines for their next teaching class, and their self-efficacy in teaching. In the same fashion, Motallebzadeh et al. (2018) and Nguyen (2017), investigate journal writing as a way of critical thinking, where they found out that reflective journal was a good tool to enhance thinking of pre-service teachers, particularly the way how they conveyed their thoughts in their narratives. While Soodmand-Afshara \& Farahanib (2017) and Leavy et al. (2006) analyse the journal writing in order to understand the development of beliefs of pre-service teachers. They claimed that as teachers move to another level of teaching, teachers are becoming more aware of their beliefs and identity as a teacher.

Although reflective teaching is an essential tool of pre-service, as well as in-service teachers' professional development in the field, as the subject of this study, there are few number of studies concerning with reflective teaching practices of pre-service student 
teachers who are teaching in a foreign classroom. Lack of empirical studies on preservice teachers teaching in foreign classroom may create a big gap between theoretical and empirical studies in the literature. The aim of this research project has therefore been to try and establish the prevalence of journal writing instruction as way of reflective teaching practices in a foreign classroom. Thus, this study proposes the following questions:

1. How do pre-service foreign teachers perceived themselves from practice to writing a reflective journal?

2. How journal writing as way of reflective practice develops pre-service foreign teachers in TESOL program?

\section{METHOD}

In this study, qualitative research was chosen because this method relies on richness and in-depth interviews research (Mason \& Fienberg, 2012) that allows researchers to obtain greater opportunity and detail to address the "how and why" questions (Yin, 2015:34). The reason of using the semi-structured interview was to ensure that the responses would address the research questions being posted in this study. This research design was chosen to explore the experiences of foreign pre-service English teachers teaching in reflective journal writing. This study was conducted after the internships for two periods of twelve weeks each, in the first semester and second semester of 2017-2018, respectively.

\section{Setting and Participants}

The present study was carried out in a four-year university department of BSE majoring in English language teaching who were currently doing their teaching practice in Thailand. The students in the program were all foreigners (see the table 1 for participant's profile) who were currently doing their teaching practice when this research study was conducted. During the four-year course in the program, pre-service teachers usually start their studies with theory (i.e. principles of teaching, SLA) and later the practice (i.e. school teaching practice). 
Table 1

Demographic data of participants

\begin{tabular}{llll}
\hline Pseudonym & Gender & Country of Origin & Level of Deployment \\
Jes & Female & Philippines *SP & Primary \\
Mich & Female & Vietnam*SP & Primary \\
Boy & Male & Malaysia* SP & Secondary \\
Telle & Female & Philippines *SP & Primary \\
Same & Male & China *ES & Secondary \\
Jhony & Femal & United Kingdom*ES & Primary \\
Marky & Male & Poland*ES & Primary \\
Amr & Female & South Africa*ES & Primary \\
Chel & Female & South Africa*ES & Primary \\
Lawrence & Male & United Kingdom*ES & Primary \\
Renz & Male & United Kingdom*ES & Primary \\
Roy & Male & South Africa*ES & Secondary \\
Mok & Female & United Kingdom*ES & Secondary \\
\hline
\end{tabular}

SP Sea program in Southeast Asia

ES Exchange student

Thus, a total of 13 pre-service foreign teachers teaching in Thailand participated in the present study. The participants of this study were enrolled in reflective journal course with 6 credits. In reflective journal course, students will be documenting and reflecting their own teaching practices, i.e. classroom behaviours, teaching methodologies and practices through journal writing. The journal writing was done within 12 consecutive weeks. Students were obliged to send their reflective journal through Google classroom platforms in each week. The submitted journals were reviewed by the assigned lecturer, and were sent it back along with the comments and aspects that pre-service teacher needs to improve. The majority of the participants were ages between 24-29, therefore, this was a 'mixed' cohort of pre-service teachers, meaning that we took into consideration that pre-service foreign teacher participants were varied when it comes to experiences and background.

\section{Data Collection and Analysis}

Prior to commencing the study, ethical clearance was sought from the participants. After obtaining their consent to participate in this study, we started then the data collection through interviewing the thirteen participants twice, once after the beginning of their teaching placement in first semester, and once after their completion from the internship program. The semi-structured interviews were employed to ask their information about (a) their earlier experiences of journal writing, (b) and, how they perceived themselves in writing a reflective journal during their internship. Each interview took approximately 75-90 minutes. The modes of interview were done in two channel; face-to-face interview was employed prior to their deployment; and second phrase was done via 
phone (as face-to-face were not possible) after their completion from the training program. The questions for the interview in both phrases were given ahead before the actual interview.

In data analysis, we followed Corbin and Strauss's (2014) constant comparative method involving open and axial coding. During the data collection, we immersed ourselves in the data by listening to the recorded interviews and taking notes and transcribing the interviews verbatim. In the open coding pace, we re-read the entire transcribed data to identify initial codes by taking marginal notes as part of the preliminary analysis. Some of the codes emerging were "Pre-service teacher's personal development," "Pre-service teacher's self-efficacy," "Pre-service teacher's professional formation.". While in the axial coding, we continued analysing the data by focusing on the relationships amongst the open codes and clustered them into categories. For instance, the following codes were bundled into the sub-category of "Pre-service teacher's personal development: critical thinking, teaching philosophy, writing styles and expression, self-actualization," "Pre-service teachers self-efficacy: anticipation, worries, preparation, and anxiety," "Pre-service teachers professional formation: teacher's metaphor, teachers belief, and teachers' identity." Depending on the codes in each category, we constructed finding statements that are empirical based on number of participants, evidence-based responses to our guiding research question. For example, the finding statement for the category of "personal development" is: pre-service teachers' response about personal view of their own development during the reflective journal writing as way of enhancing critical thinking was categorized under critical thinking. In the remainder of this article, we present and discuss each finding with illustrative examples from the data.

\section{FINDINGS}

This study has formed three main themes and subthemes as reflected from the research questions. For the purpose of presentation, directly quoted interview excerpts were given below. Pseudonyms are used for the pre-service foreign-teacher's participants (see the appendix 1 for the summary of the result).

\section{Theme 1: Pre-service teachers' personal development}

\section{a. critical thinking}

According to the interview data, most of the pre-service teachers revealed that reflective writing helped them to build up their critical thinking abilities.

I have become more aware of the ability to think clearly and rationally, following and understanding the logic between ideas, [ Boy]

I think an effective critical thinker makes a major contribution to being an effective teacher. I feel I have developed my thinking ability in the categories of theories, planning and reflection and dilemmas and uncertainty. [ $\mathrm{Le}]$

Others revealed that doing a reflective journal aided them to check the challenges they have faced during the teaching process. 
It's made me be more creative with delivering the lessons after doing the lesson and reflecting on what challenged me and the results it's made pushed me to be more creative in lesson planning to fulfil the challenges of quality delivery. [Ser]

My critical thinking skills have improved to the extent that I can now extend the variety and content of my lessons. [Jhon]

For sustainable development of my students and for my progress as well I hone the critical thinking skills of my students opening up a new lifetime of intellectual curiosity. [Marky]

From the responses above, it can be seen that journal writing as a reflective practice helps pre-service teachers to enhance their critical thinking, not only to the teaching aspects but also to their lesson planning.

\section{b. teaching philosophy}

The result showed that most pre-service teachers (12) believed that journal writing was a way of constructing their teaching philosophy.

I have learned the importance of having teaching philosophies. I had never really thought about why I teach the way I do. [Chel]

Reflective practices improved my educational philosophical perspective by outlining my beliefs about teaching practices. [Lawrence]

These result demonstrated that journal writing was good avenue for pre-service teachers to realize their teaching philosophy from theory to practice which could guide them for their teaching practices.

\section{c.writing styles and self-expression}

Pre-service teacher's participants perceived that journal writing helped them in developing their writing style and also through journal writing they had expressed themselves that in consultation.

Doing feedback has definitely influenced the way I write about my lessons. I am more specific in my examples. I used to write vague statements such as "most of my students completed the activity'. However, I now give specific numbers and examples such as ' 10 students completed the activity and made no errors'. [ Renz]

My experiences were able to alter my abilities and show that there is not only one style of writing and self-expression. [ Mok]

Over the past 12 weeks I have developed my writing style in numerous ways; being clear and to the point, being concise and using fewer words where possible, paying more attention to my choice of words and using words that come naturally to me, not using words to sound impressive or misusing words that I'm not familiar with. [ Rich]

Other pre-service teacher participants also reported that they feel more challenging when the teachers corrected their weekly reflective journal. Two teachers [Bared and Chatelle] disclosed, 
I have found more challenging if I am corrected by my mentor. It shows that I am guided and evaluated in terms of my writing skills. Honestly speaking I am not good in writing in expressing myself. [Ser]

I think after these 12 weeks I'm able to express myself better in my reflections. I find it easier to identify my own errors or strong points. I do my best to outline the objectives and ensure they are met by the end of each lesson. [ Jhon]

\section{d. self- actualization}

As a fourth subtheme, the analysis revealed that journal writing was viewed as selfactualization as novice teachers in the field.

The development of my reflective abilities has noticeably improved by enforcing action on personal reflection. This strategy helped improve and solve classroom practices and problems. Intellectual reflection reduced anxiety and linked gaps that pre-exist from desired goals and previously acquired knowledge. [ Amr]

I have developed the ability for reflection; it is new to me and something that I have regrettably not done in the past. [Lawrence]

I found that I more readily reflect on the effectiveness of each lesson. I analyze what went well and what didn't go according to plan and how to improve on these in the future. [Ren]

Another pre-service teacher said:

I have realized the importance of identifying a measurable objective. In the first couple journals I overlooked the importance, but now I understand that without a measurable objective, it's impossible to know if a student has learned anything from the lesson. [Renz]

\section{Theme 2: Pre-service teachers' self-efficacy}

Pre-service teacher-participants also revealed self-efficacy in teacher. They reported their anticipation, worries, anxiety, and preparation in teaching.

\section{a.anticipation}

The consistent response from the pre-service teachers mirrored the reflecting-in-selfefficacy of pre-service teachers in twelve weeks of journaling. Subtheme of anticipation surfaced in statements such as the following.

When preparing for my students, I did experience a lot of anxiety. I was concerned about my lessons being interesting while also educational for the students. [Jes]

My anticipations for my students during these past 12 weeks was getting them interested and active in the lesson and removing anxiety. [Boy]

One pre-service participant [ Laurent] said:

I feel that through weekly reflection, I built the ability to respond to the anxiousness. Because when I was writing I always reflect to myself and looking for possible solutions on how to surpass this kind of anxiety in me. 


\section{b. worries}

Although twelve pre-service participants perceived relaxed in their teaching practice, three pre-service teachers, however, reported that they felt worried during their practice.

I did doubt my abilities quite often. When a lesson was too easy or too challenging for my students, I worried that I had misjudged their abilities. [Mok]

Even though I prepared it for them but my worry was maybe they cannot get the point or the concept that I want them to learn. [Renz]

During the 12 weeks in practice, the only worries I have experienced have been prior to the lessons. Anxious to know if each lesson would be a success or not go as planned. [Ren]

Other pre-service teachers also reported that she felt worried because of the curriculum being implemented in their school was quite confusing. One teacher claimed,

These past 12 weeks I worried about some of the curriculum being either too hard or not relevant to my students which impacted on me as I had a hard time developing creative teaching strategies and methods in delivering the lessons in a more interesting manner. [lawrence]

These statements reflect a sense of professional responsibility for pre-service teachers which led them to feel worried.

\section{c. preparation}

Another subtheme formed was self-efficacy of pre-service teachers in preparing of themselves which includes their lesson and materials.

When I received each lesson that I was ordered to teach, I spent some time researching different methods and activities that I could use. I looked for songs and practiced actions and dance moves that I could show my students. [ Marky]

My preparation was to go into the lesson understanding the content of particular course books. I also prepared many visual prompts which helped facilitate our sessions. [ Mok]

Most of my preparations were developing prompts and activities to make each topic more interesting and interactive to my students.as well as teaching strategies and methodologies on how to get the most out of the 50minute lesson period. [ Mich]

\section{d. anxiety}

Two pre-service teachers summed up their anxiety experiences with the following analogy:

I used to suffer with a lot of anxiety when teaching. Doing feedback has helped identify the source of this anxiety. I feel most stressed when I have not prepared properly or am procrastinating. [ Jes]

I found my levels of stress lower a bit as I felt a bit more prepared for my lessons, and also comfortable with the idea that some elements of the lesson might not work but it is ok and that I would be able to adapt my lesson at such a time. [ Chel] 
Another pre-service teacher mentioned that he felt minimal stress, he claimed that,

My life as a teacher comes with minimal stress and anxiety and I am forever grateful for that. At my current school everything is very well organized and all resources and curriculums are provided so once I leave work I can focus on myself. [Ser]

\section{Theme 3: Pre-service Teachers' formation}

\section{a. teachers' metaphor}

Most of the pre-service teachers revealed that journal writing as reflective practice enables pre-service teacher to construct their metaphors in teaching.

I also believe that teaching is an art and that teachers are artists. It takes a lot of time and skill to get it just right. Sometimes, art doesn't turn out the way you want it to. But you learn from mistakes and keep trying to improve. [Chel]

For me, teaching is just like a Lamplighters and Gardeners: Cultivate the minds by enhancing climate, standing back to allow learners to grow. [Ren]

According to their responses, it seemed that pre-service teachers constructed their metaphor based on their principle of teaching, as well as their experiences in their teaching.

b. teachers' belief

Another subtheme formed in the data interview was their beliefs in teaching which was built during their reflective writing.

For me it's not only just teaching the students the lesson but understanding also them is important. The weakness and strengths of my students help me to adjust my lesson. I Mich]

My biggest belief over the 12 weeks of practice is that learning should be fun (in kindergarten). This means that I should make my class enjoyable to my students in order to foster their learning. [Boy]

I believe that the best way to learn a new language is to be fully engaged with it and practice using it as much as possible. [ Renz]

It can be seen that pre-service teachers explored their partial belief in teaching and learning which these are usually held tacitly and build up over their professional development.

c. pre-service teachers' identity

Findings also revealed that most of the pre-service teachers construct and reconstruct a conceptual sense of who they are inside the classroom which resulted through what they do.

I feel as though I have gained some very useful pointers from the instructor during my practice. I feel confident as a teacher, and I have learnt of the importance of measuring objectives. My role was to guide them to achieve their objectives. [Mok] 
Most of the time I am a mentor and facilitator, occasionally I am a judge, and disciplinarian. [Lawrence]

If I am self- aware, I am better able to empower students, and therefore enhance learning. An area where self- awareness is important is regarding cultural beliefs and biases, which definitely affect teaching effectiveness. [Renz]

\section{DISCUSSION}

The present study aims to explore the experiences of 13 pre-service English teachers teaching in reflective journal writing in a foreign context. Thorough the interview data, pre-service teachers perceived both challenges and benefits in writing a journal. Some participants have seen that reflective journal helped them to facilitate, monitor, and evaluate their own teaching and learning practices. This finding corroborates the ideas of Shu-ping (2012);Leong \& Mardziah (2006) ; Collin et al. (2013); Cornish (2012); Thompson \& Pascal (2012), where they highlight that journal writing is essential tool in teachers training program, i.e., professional and individual development, teachers' identity formation, and their self-efficacy as a newcomer in the field of teaching. Through reflective journaling, it enhances pre-service teachers with regards to their learning and teaching comprehensively and systematically. This rather contradictory to some studies noting that reflective journal is seen to be time consuming in evaluating pre-service teachers' performance (Lakshmi,2012; Liu \& Milman,2010; Teekman ,2000; Spencer,2003)

One unanticipated finding was that pre-service teachers noted that reflective journal writing was an encouraging tool for their professional development, critical thinking, and evaluating their daily performances. This finding is in agreement with Carosotto's ( 2017); Leitch and Day's (2000); Choy and Oo's ( 2012); Ross's (2011) ; and, Mason's ( 2004) findings which showed critical thinking is anchored to reflective journal writing as pre-service teachers has to think on how they reflected their experiences into writing which required them to think critically and honestly. It is also noted that most of the participants mentioned that reflective journaling allowed them to reflect on their personal abilities as a teacher. For example, some participants mentioned that they could be able to cross upon their teaching strategies, teaching methods, and the way how they teach the lesson, as well the quality of their teaching. Surprisingly, pre-service teachers acknowledged that though daily reflections helped them to realize their teaching philosophy. This confirm the study of Akbari (2007); Owens et al.(2014); and Thorpe, (2004), who claimed that daily reflection enables teachers, learners, and individual to evaluate their teaching beliefs and philosophy whether it is suitable to their immediate community. However, Khanjani et al. (2017) mentioned that this stage is also a good avenue to confirm their theoretical knowledge in teaching as they are exposed on the reality of their profession.

Consequently, pre-service teachers admitted that their daily reflective journal writing helped them to develop their writing styles, particularly on its content and structure. For example, some participants mentioned that when they report what has happened in their teaching, they were now able to justify and give factual information that support their narratives. They also distinguished the importance of teacher's feedback in their output, 
as for some of them noted that their teachers' feedback on their weekly reflection helped them to correct some mistakes in their teaching, i.e., the lesson, activities. Gil-Garcia and Cintron (2012); Jacob et al. (2011); and, Farrah (2012) observe, teachers' feedback on students' output is highly regarded in this kind of platform, as students need evaluator of their performance and thus direct them to the right path of their professional development. Moreover, most of the participants disclosed that reflective journaling helped them to express their own self as they were able to demonstrate their daily practices on a record. However, some pre-service teachers reported difficulties in writing due to their ability in writing, time management, and also to the things they must put on their reflection. These difficulties are support the study Nguyen (2017), where he claimed that teachers could not fully engage themselves in this platform due to these difficulties, and thus affect their teaching practices. In contrast to the statement of Motallebzadeh et al. (2018); and, Richards and Farrell (2006), who argue that whatever difficulties they may encounter in reflective practice, still the main goal is to seek improvement, pedagogic solutions, and evolutions of teaching as teachers strive towards the edge of self-actualization.

Participants also reported their self-efficacy during their teaching, namely; anticipation, worries, preparation, and anxiety. These self-efficacy beliefs have guided pre-service teachers on the effectiveness of their teaching practice. Although some pre-service teachers claimed that, they felt anxious and worried during their practice, but they still perceived willingness to teach due to the idea that they need to write something in their reflection. This phenomenon in self-efficacy of reflective practice appears to be similar with the findings of Cabaroglu (2014), where she claimed that teachers anxiousness may positively influence teachers as they do not have any option but to anticipate and prepare in order to deliver their lessons properly. Another justification for the preservice teachers' self-efficacy as form of reflective practice might be related to the gap existing between theory and practice by Minott (2011) and Farrell (2013), where they highlighted that teacher efficacy is associated with how the teachers reflected on their daily teaching practice.

Findings also underlined that journal writing for reflective practice could construct teacher's metaphor and professional identity. It reveals that teachers' metaphor in this study is dynamic, and it shifts over time under the influence of range factors both internal or external factors. For example, some participants claimed that they assumed that their role would be just a facilitator of knowledge, but when time goes by they realized that their role seemed to be an adviser as they need to advise what learners have to do in the learning process. This shifting of teachers' metaphor was reported by Farrell (2013); McGlone (2007); Parks (2010); and Saban (2004), who reported that teacher changes their role due to the influence of the context of their current community. Hence, giving teacher's metaphor is the easiest way to remember their role inside of the classroom which could help them to understand the quality of their teaching and their responsibility in the teaching process. However, these metaphors have an internal consistency and coherence of their practices, which provide prelims into ideas that are not consciously held in the teaching practice. 
Apart from these, findings also suggested that journal writing for reflective practice helped pre-service teachers to (re) construct their professional identity in their community of practice. For example, eight participants mentioned that they struggled on how they teach the students due to their teaching knowledge in EFL ( English as Foreign Language ) context which resulted them to adopt and change their teaching approaches. The findings of the study in this regard is also in agreement with those of Conway (2001); Flores and Day (2006); Hammerness (2006); and Parkison (2008), who asserted that association of teachers' identity and reflective practice, particularly on how new beginner teachers' negotiate their competence in the society. Their professional role identity is not only a periphery of reflective teaching quality, but it also influences on how they teach inside the classroom. Thus, journal writing for reflective practice aided pre-service teachers to uncover their identities, as it fundamental in teachers-to-be (Na \& William, 2010; Pendergast et al., 2011).

Together, these accounts from pre-service teachers demonstrated both the impact and the factors affecting their teaching practices. It is argued in this study that teacher institute must include reflective journaling as a way of evaluating and monitoring preservice teachers. If the lesson plan is mandated before teaching, it also argued that reflective journaling would be imposed at the end of the lesson as a confirmatory stage whether the lesson was delivered properly or not.

Although the present study claims that journal writing for reflective practice is good tool to facilitate pre-service teachers in developing their professional knowledge, constructing their identities, teachers' metaphor, and beliefs about teaching and learning, there are limitations with regards to participants and focus. As this study has only 13 pre-service teachers as participants, the data gathered and the findings may not provide a sound representation representation of all pre-service teachers training who have been currently enrolled in any international programs. Hence, research studies on journal writing for reflective practice with a different methodology are recommended. Future research studies may compare and analyze the content of pre-service teacher's lesson plan and with their reflective journal. Curriculum designer may also include reflective journal course in their curriculum - an area in which course remains sparse, especially in ASEAN context.

\section{CONCLUSION}

In the current study, we found out that journal writing for reflective practice is generally valued by pre-service teachers and seen as contributing to their individual development. The present study attempted to identify the prevalence of reflective teaching practices through reflective journaling of 16 foreign pre-service English teachers teaching in Thailand. The findings suggested that journal writing for reflective practice is good tool to facilitate pre-service teachers in developing professional knowledge, constructing their identities, beliefs and metaphor which could bring with them a myriad of experiences, assumptions, and beliefs about teaching and learning. However, finding time to reflect can be a problem for some, in line with the findings of Christie and Kirkwood (2006); Fatemipour and HosseingholiKhani(2014); Gray (2000), where reflective journal could hinder the learning process of the pre-service teachers. 
Evidently, journal writing as way of reflective practice are more effectively when they are privy to pre-service teachers' implicit thought processes, the philosophy and feelings underlying those thoughts, and the basis for decision-making strategies. In which, the sincerity towards the reflection is the only key to make the reflective journal a success that may produce a valuable outcome towards teaching-learning process.

The findings were supported by the study conducted by Russell (2005), who emphasizes on the effect of journal writing that could create awareness towards pre-service teachers about their teaching strategies inside the classroom. In addition to this, Khanjani et al. (2018) relates to the use of journal writing as part of reflective approach practices that pre-service teachers can use. Even in the study of Nguyen (2017) it was revealed that with the use of journal writing it enhances the critical thinking skills of pre-service teachers. It can be depicted that with the proper implementation and guidance of the journal writing, positive outcome can be shown to the pre-service teachers teaching performance. This combination of findings provides some support for the conceptual premise that curriculum designer could consider reflective journal courses to facilitate pre-service teachers' development, learning, and instruction. Given these premises, future research should explore the effect and impact of reflective journal in TESOL program considering that reflective journal requires time and effort for pre-service teachers to reflect.

\section{REFERENCES}

Al-karasneh, S. M. (2014). Reflective journal writing as a tool to teach aspects of social studies. European Journal of Education, 49(3), 395-408.

Abednia, A., Hovassapian, A., Teimournezhad, S., \& Ghanbari, N. (2013). Reflective journal writing: Exploring in-service EFL teachers' perceptions. System, 41(3), 503-514.

Akbari, R. (2007). Reflections on reflection: A critical appraisal of reflective practices in L2 teacher education. System, 35(2), 192-207. doi:10.1016/j.system.2006.12.008.

Burgoyne, M. B., \& Chuppa-Cornell, K. (2018). 'If I tried this idea again: developing faculty professional growth through reflective practice. Journal Reflective Practice: International and Multidisciplinary Perspectives, 19(6), 818-831. https://doi.org/10.1080/14623943.2018.1539656.

Bolton, G. (2010). Reflective practice, writing and professional development. Los Angeles, Calif:: SAGE.

Boud, D. (2001). Using journal writing to enhance reflective practice. In L. M. English, \& M. A. Gillen (Ed.), Promoting journal writing in adult education (pp. 44-56). San Francisco, Calif.: Jossey-Bass.

Bruster, B. G., \& Peterson, B. R. (2013). using critical incidents in teaching to promote reflective practice. Reflective Practice: International and Multidisciplinary Perspectives 14(2), 170-182.

Burton, J., \& Carroll, M. (2001b). Journal writing as an aid to self-awareness, autonomy and collaborative learning. In J. Burton, \& M. Carroll (Ed.), Journal writing (pp. 1-7). Alexandria, VA: TESOL. 
Burton, J. (2005). The importance of teachers writing on TESOL. TESL-EJ, 9(2), 1-18.

Burton, J. (2009). Reflective practice. In A. Burns \& J.C. Richards (Ed.), The Cambridge guide to second language teacher education (pp. 298-307). Cambridge, UK: Cambridge University Press.

Carosotto, C. (2017). Writing in journals as a tool for expressing ourselves: A 6-8 Week Long writing curriculum for a 3rd/4th grade, self-contained, special education classroom. New York: Bank Street College of Education. Retrieved from https://educate.bankstreet.edu/independent-studies/187.

Chien, C. W. (2013). Analysis of a language teacher's journal of classroom practice as reflective practice. Reflective Practice, 14(1), 131-143. doi:10.1080/14623943.2012.732951

Choy, S. C., \& Oo, P. S. (2012). Reflective thinking and teaching practices: A Precursor for incorporating critical thinking into the classroom? Online Submission, 5(1), $167-$ 182.

Nguyen, C. (2017) Connections between learning and teaching: EFL teachers' reflective practice, Pedagogies: An International Journal, 12(3), 237-255, doi: 10.1080/1554480X.2017.1356725.

Christie, D., \& Kirkwood, M. (2006). The new standards framework for Scottish teachers: facilitating or constraining reflective practice? Practice, 7(2), 265-276.

Collin, S., Karsenti, T., \& Komis, V. (2013). Reflective practice in initial teacher education: Critiques and perspectives. Reflective Practice 14(1), 104-117.

Cornish, L., \& Jenkins, K. A. (2012). Encouraging teacher development through embedding reflective practice in assessment. Asia-Pacific Journal of Teacher Education, 40(2), 159-170.

Conway, P. F. (2001). Anticipatory reflection while learning to teach: From a temporally truncated to a temporally distributed model of reflection in teacher education. Teaching and Teacher Education, 17(1), 89-106.

Farrell, T. S. C. (2013). Teacher self-awareness through journal writing. Reflective Practice, 14(4), 465-471. doi:10.1080/14623943.2013.806300

Farrell, T. S. C. (2006). The teacher is an octopus. RELC Journal, 37(2), 236-248. doi: $10.1177 / 0033688206067430$.

Fatemipour, H., \& Hosseingholi Khani, F. (2014). The impact of reflective teaching on the EFL teachers' performance. Journal of Education and Management Studies, 4(4), 796-799.

Farrah, M. (2012). Reflective journal writing as an effective technique in the writing process. An - Najah Univ. J. Res. (Humanities), 26(4), 997-1025.

Flores, M. A., \& Day, C. (2006). Contexts which shape and reshape new teachers' identities: A multi-perspective study. Teaching and Teacher Education, 22(2), 219-232. 
Gadsby, H., \& Cronin, S. (2012). To what extent can reflective journaling help beginning teachers develop masters level writing skills? Reflective Practice. International and Multidisciplinary Perspectives, 13(1), 1-12.

Garza, R., \& Smith, S. F. (2015). Pre-service teachers blog reflections: Illuminating their growth and development. Cogent Education, 2(1), 1066550. doi:10.1080/2331186x.2015.1066550

Gil-Garcia, A., \& Cintron, Z. (June, 2002). The reflective journal as a learning and professional development tool for teachers and administrators. Paper presented at the World Association for Case Method Research and Application Conference. Germany. July 2-5. Retrieved from http://www.eric.ed.gov/ERICWebPortal /search/detailmini.jsp?_nfpb.

Gould, N., \& Taylor, I. (2017). Reflective learning for social work: research, theory and practice. London: Routledge.

Gray, J. (2000). Training for reflective practice: Getting the most out of pre-service courses. The Teacher Trainer, 14, 14-17.

Grushka, K., McLeod, J. H., \& Reynolds, R. (2005). Reflecting upon reflection: Theory and practice in one Australian university teacher education program. Reflective Practice, 6(2), 239-246.

Glogger, I., Schwonke, R., Holzäpfel, L., Nückles, M., \& Renkl, A. (2012). Learning strategies assessed by journal writing: Prediction of learning outcomes by quantity, quality, and combinations of learning strategies. Journal of Educational Psychology, 104(2), 452-468. doi:10.1037/a0026683 52.

Hammerness, K. (2006). Seeing through teachers' eyes: Professional ideals and classroom practice. New York: Teachers College Press.

Haugan, J. A., Moen, T., \& Karlsdóttir, R. (2013). Exploration of Norwegian student teachers' reflective mediation during internships. Reflective Practice, 14(2), 226-239. doi:10.1080/14623943.2012.749233

Hickson, H. (2011). Critical reflection: Reflecting on learning to be reflective. Reflective Practice: International and Multidisciplinary Perspectives 12(6): 829-839.

Jacobs, M., Vakalisa, N. C. G., \& Gawe, N. (2011). Teaching-learning dynamics. Cape Town: Pearson.

Johnson, K. E., \& Golombek, P. (2002). Teacher's narrative inquiry as professional development. Cambridge, UK: Cambridge University Press.

Khanjani, A., Vahdany, F., \& Jafarigohar, M. (2018). Effects of journal writing on EFL teacher trainees' reflective practice. Research in English language pedagogy, 6(1), 5677.

Lakshmi, B. S. (2012). Reflective practice through video recording and journal writing-a case study. 3L; language, linguistics and literature, The Southeast Asian Journal of English Language Studies, 18(4), 193-201. 
Liu, L., \& Milman, N. (2010) Preparing teacher candidates to teach diverse student populations through reflective practice. Reflective Practice, 11(5), 619-630. doi:10.1080/14623943.2010.516973.

Lee, I. (2007). Preparing pre-service English teachers for reflective practice. ELT Journal, 61(4), 321-329.

Leavya, A., McSorleya, F., \& Bote, L. (2006). An examination of what metaphor construction reveals about the evolution of preserve teachers' beliefs about teaching and learning. Teaching and Teacher Education, 23, 1217-1233.

Leitch, R., \& Day, C. (2000) Action research and reflective practice: towards a holistic view. Educational Action Research, 8(1), 179-193.

Leong, I. Y. C., \& Abdullah, M. H. (2017). Reflective practice in language teaching. The English Teacher, XXXVI, 34-46.

Mason, W. M., \& Fienberg, S. (Eds.). (2012). Cohort analysis in social research: Beyond the identification problem. New York: Springer-Verlag.

Mason, R., Pegler, C., \& Weller, M. (2004). E-portfolios: An assessment tool for online courses. British Journal of Educational Technology, 35(6), 717-727.

McGlone, M. S. (2007). What is the explanatory value of a conceptual metaphor? Language \& Communication, 27, 109-126.

Minott, M. A. (2009). Reflection and reflective teaching, a case study of four seasoned teachers in the Cayman Islands. Germany: VDM Verlag Dr. Müller, Aktiengesellschaft.

Motallebzadeh, K., Ahmadi, F., \& Hosseinnia, M. (2018). The relationship between EFL teachers' reflective practices and their teaching effectiveness: A structural equation modeling approach. Cogent Psychology, 5(1), 1424682.

Moon. J. A. (2000). Reflection in learning and professional development: Theory and practice. London: Routledge.

Moradkhani, S., Raygan, A., \& Moein, M. S. (2017). Iranian EFL teachers' reflective practices and self-efficacy: Exploring possible relationships. System, 65, 1-14.

Na, W., Nicholas, H., \& Williams, A. (2010). School experience influences on preservice teachers' evolving beliefs about effective teaching. Teaching and Teacher Education, 26(2), 278-289. doi:10.1016/j.tate. 2009.03.010.

O'Brien, G. J. (2016). A scenario for change: reflective practice for post-ordination professional development. Reflective Practice, 17(4), 379-392. doi:10.1080/14623943.2016.1164684

Orland-Barak, L., \& Yinon, H. (2007). When theory meets practice: What student teachers learn from guided reflection on their own classroom discourse. Teaching and Teacher Education, 23(6), 957-969.

Ortlipp, M. (2008). Keeping and using reflective journals in the qualitative research process. The Qualitative Report, 13(4), 695-705. 
Owens, L. W., Miller, J. J., \& Grise-Owens, E. (2014). Activating a teaching philosophy in social work education: Articulation, implementation, and evaluation. Journal of Teaching in Social Work, 34(3), 332-345.

Parks, A. N. (2010). Metaphors of hierarchy in mathematics education discourse: The narrow path. Journal of Curriculum Studies, 42(1), 79-97.

Parkison, P. (2008). Space for performing teacher identity: Through the lens of Kafka and Hegel. Teachers and Teaching: Theory and Practice, 14(1), 51-60.

Pavlovich, K. (2007). The development of reflective practice through student journals. Higher Education Research \& Development, 26(3), 281-295. doi:10.1080/07294360701494302.

Pendergast, D., Garvis, S., \& Keogh, J. (2011). Pre-Service Student-Teacher Selfefficacy Beliefs: An Insight into the Making of Teachers. Australian Journal of Teacher Education, 36(12). doi:10.14221/ajte.2011v36n12.6.

Richards, J., \& Farrell, T. (2005). Professional development for language teachers. Cambridge: Cambridge University Press.

Ross, N. (2011). Reflective writing: An approach to developing critical thinking and proficient writing (Unpublished master thesis). United States Military Academy. U.S.A.

Roux, R., Mora, A., \& Tamez, A. (2012). Reflective writing of Mexican EFL writers: Levels of reflection, difficulties and perceived usefulness. English Language Teaching, 5(8), 1-13.

Russell, T. (2005). Can reflective practice be taught? Reflective Practice, 6(2), 199-204.

Saban, A. (2004). Prospective classroom teacher's metaphorical images of selves and comparing them to those they have of their elementary and cooperating teachers. International Journal of Educational Development, 24, 617-635.

Shu-ping, L. I. (2012). Study on professional development of foreign language teachers in agricultural universities from the perspective of reflective teaching. Journal of Anhui Agricultural Sciences, 15, 050.

Slepcevic-Zach, P., \& Stock, M. (2018). ePortfolio as a tool for reflection and selfreflection. Reflective Practice, 19(3), 291-307. doi:10.1080/14623943.2018.1437399

Spalding, E., \& Wilson, A. (2002). Demystifying reflection: A study of pedagogical strategy that encourage reflective journal writing. Teachers College Record, 104(7), 1393-1421.

Soodmand Afshar, H., \& Farahani, M. (2018). Inhibitors to EFL teachers' reflective teaching and EFL learners' reflective thinking and the role of teaching experience and academic degree in reflection perception. Reflective Practice, 19(1), 46-67.

Spencer, S.A. (2003). Language teacher as language learner: Identity loss and other issues. The Language Teacher, 27(1), 9-12.

Teekman, B. (2000) Exploring reflective thinking in nursing practice. Journal of Advanced Nursing, 31, 1125-1135. 
Thorpe, K. (2004). Reflective Learning Journals: From Concept to Practice. Reflective Practice, 5, 328-343. http://dx.doi.org/10.1080/1462394042000270655.

Thompson, N., \& Pascal, J. (2012). Developing critically reflective practice. Reflective Practice, 13(2), 311-325. doi:10.1080/14623943.2012.657795

Varner, D., \& Peck, S. (2003). Learning from learning journals: The benefits and challenges of using learning journal assignments. Journal of Management Education, 27(1), 52-77.

Yin, R. K. (2015). Qualitative research from start to finish. Guilford Publications.

Yeom, Y., Miller, M. A., \& Delp, R. (2018). Constructing a teaching philosophy: Aligning beliefs, theories, and practice. Teaching and Learning in Nursing, 13(3), 131134. doi:10.1016/j.teln. 2018.01.004.

Zulfikar, T., \& Mujiburrahman. (2017). Understanding own teaching: Becoming reflective teachers through reflective journals. Reflective Practice, 19(1), 1-13. doi: 10.1080/14623943.2017.1295933. 
Appendix 1

Coding system

\begin{tabular}{ll}
\hline Themes & Sub-theme \\
\hline 1.Pre-service personal development & 1.critical thinking \\
& 2. teaching philosophy \\
& 3.writing styles and self expression \\
& 4.self-actualisation \\
\hline 2.Pre-service teachers' self- efficacy & 1. anticipation \\
& 2. worries \\
& 3. anxiety \\
\hline 3.Pre-service teachers' identity formation & 1.teachers' metaphor \\
& 2. teachers' belief \\
& 3. teachers' identity \\
\hline
\end{tabular}

